\title{
Activin-related proteins in bovine mammary gland: Localization and differential expression during gestational development and differentiation
}

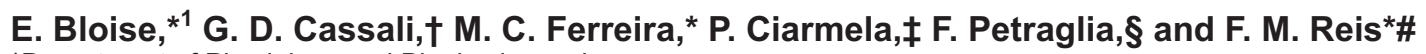 \\ *Department of Physiology and Biophysics and \\ †Department of General Pathology, Federal University of Minas Gerais, 31270-901 Belo Horizonte, Brazil \\ †Department of Molecular Pathology and Innovative Therapies, Polytechnic University of Marche, 60020 Ancona, Italy \\ $\S$ Department of Pediatrics, Obstetrics and Reproductive Medicine, University of Siena, 53100 Siena, Italy \\ \#Department of Obstetrics and Gynecology, Federal University of Minas Gerais, and National Institute of Hormones and Women's Health, \\ 30130-100 Belo Horizonte, Brazil
}

\begin{abstract}
Bovine mammary gland morphogenesis and differentiation are regulated by actions of growth factors including members of the transforming growth factor $\beta$ superfamily. Activins $\mathrm{A}$ and $\mathrm{B}$, which are members of the transforming growth factor $\beta$ superfamily, bind selectively to ActRIB and ActRIIA receptors and their biological effects are antagonized by inhibins and follistatins. In the present paper we evaluated gene and protein expression of the activin and inhibin subunits $\beta \mathrm{A}, \beta \mathrm{B}$, and $\alpha$-inhibin and follistatin and ActRIB and ActRIIA receptors in the mammary gland of nonpregnant and pregnant heifers. Mammary glands were obtained from nonpregnant Nelore (Bos indicus) heifers $(\mathrm{n}=9)$ and from primigravid Nelore heifers during early $(\mathrm{n}=9)$, mid $(\mathrm{n}=6)$, and late $(\mathrm{n}=5)$ pregnancy. Specimens of mammary tissue were analyzed by realtime PCR and immunohistochemistry. The $\beta \mathrm{A}$ and $\alpha$-inhibin subunits and ActRIB and ActRIIA mRNA expression was higher in the early-pregnancy group compared with the nonpregnant group. In the midpregnancy group, the subunits $\beta \mathrm{A}, \beta \mathrm{B}$, and $\alpha$-inhibin as much as follistatin mRNA expression was higher compared with the nonpregnant group, whereas ActRIB transcripts were absent in the late-pregnancy group. Immunostaining of these proteins, with the exception of ActRIB, was observed in the mammary tissue sections at all time points analyzed; these findings are in agreement with the observed pattern of mRNA expression. Staining and mRNA expression for ActRIB were undetected in the late-pregnancy group. In summary, the present study demonstrated that the activin-related proteins, $\beta \mathrm{A}, \beta \mathrm{B}$, and $\alpha$-inhibin subunits, as much as follistatin and ActRIB and ActRIIA receptors display different patterns of expression regarding time of gesta-
\end{abstract}

Received December 8, 2009.

Accepted July 2, 2010.

${ }^{1}$ Corresponding author: enrico_bloise@hotmail.com tion in the bovine mammary gland. The modulation of the expression pattern during gestation suggests that activin-related proteins may play a key role in regulating bovine mammary branching morphogenesis and epithelial differentiation.

Key words: activin, inhibin, follistatin, mammary gland

\section{INTRODUCTION}

Transforming growth factor $\beta$ (TGF- $\beta$ ) superfamily members play a key role in regulating mammary epithelium proliferation and are important mediators of mammary gland morphogenesis, development, and differentiation (Robinson and Hennighausen, 1997; Daniel et al., 2001; Akers, 2006; Manickam et al., 2008; Montesano et al., 2008; Bierie et al., 2009). The TGF- $\beta$ superfamily contains more than 30 members including TGF- $\beta$, bone morphogenetic proteins, growth and differentiation factors, activins, and inhibins. These molecules regulate several cellular functions such as growth, adhesion, migration, apoptosis, and differentiation and have remained well conserved during evolution (Feng and Derynck, 2005). Activins in particular are vital for embryonic development and morphogenesis of most organs, including the mammary glands (Robinson and Hennighausen, 1997).

Activins and inhibins display $97 \%$ of homology among large domestic animal species (Phillips, 2005). Activins are dimers comprising $2 \beta$ subunits $(\beta \mathrm{A}$ or $\beta \mathrm{B})$; therefore, 3 possible activins exist: $\mathrm{A}(\beta \mathrm{A} / \beta \mathrm{A})$, $\mathrm{B}(\beta \mathrm{B} / \beta \mathrm{B})$, and $\mathrm{AB}(\beta \mathrm{A} / \beta \mathrm{B})$ (Muttukrishna et al., 2004). They bind initially to their type II receptor, ActRIIA or ActRIIB, which leads to the recruitment, phosphorylation, and subsequent activation of the type I receptor, ActRIB. Upon activation, ActRIB binds and then phosphorylates a subset of the cytoplasmic signaling proteins of the Smad family (Smad 2, Smad 3, and Smad 4), forming a complex that translocates toward the nucleus and modulates gene expression (Harrison et al., 2005; Schmierer and Hill, 2007). Importantly, 
activins bind selectively to the ActRIB and ActRIIA receptors; ActRIA and ActRIIB in turn, bind indiscriminantly to other TGF- $\beta$ superfamily members (Lin et al., 2006; Komatsu et al., 2007). Activin bioactivity is regulated by various extracellular proteins such as inhibins and follistatins. Inhibins antagonize activins by binding to ActRII receptors and are formed by $1 \alpha$ and $1 \beta \mathrm{A}$ (inhibin A) or $\beta \mathrm{B}$ (inhibin B) subunit (Harrison et al., 2005; Bilezikjian et al., 2006). Whereas follistatin (FS) is an activin-binding single-chain glycoprotein that exists in 3 isoforms that differ in cell surface proteoglycans binding properties, FS-288 and FS-315 are formed by alternative splicing and FS-303 is generated from the proteolytic cleavage of FS-315 (Sidis et al., 2002; Schneyer et al., 2004; Saito et al., 2005).

In mice, activins and inhibins play a pivotal role in mammary gland organogenesis. Actually, $\beta \mathrm{B}$ subunit knockout mice do not produce milk. Instead, they exhibit impaired ductal branching and epithelium differentiation during gestation, and at parturition alveolar lumina fail to expand because of the absence of secreted milk (Robinson and Hennighausen, 1997). Moreover, activin-related proteins have been detected during nongestational and lactational mammary gland development in mice, with a growth regulatory role in lactation being suggested (Jeruss et al., 2003). Regarding the physiological functions of activins in the mammary gland, experiments performed in isolated cultured acini demonstrated that activin A inhibited cell proliferation and downregulated the expression of $\beta-\mathrm{CN}$ by blocking prolactin/signal transducer and activator of transcription 5 (STAT5) signaling, thus showing a role in modulating an important lactogenic pathway (Bussmann et al., 2004; Cocolakis et al., 2008). Such antiproliferative effect was also identified in human breast cancer cell lines, where activin A arrested cells in the G0/G1 (gap 0/gap 1) cell cycle phase (Liu et al., 1996; Burdette et al., 2005). Similarly, in the bovine species, in vitro experiments have demonstrated that TGF- $\beta$ treatment has an inhibitory effect on bovine epithelial cell growth (Akers, 2006). Such effect might modulate branching morphogenesis because cultured mouse mammary epithelial tubules start branching at sites with minimum local concentrations of TGF- $\beta$ growth factors (Nelson et al., 2006; Montesano et al., 2007). In accordance with an inhibitory growth effect, TGF- $\beta 1$ transcripts are higher during developmental phases in which a great tissue remodeling is occurring in the mammary gland (Plath et al., 1997). Altogether, TGF- $\beta$ superfamily members have been related to mammary growth and function and therefore are important growth factors that may influence milk production.

Based on the $\beta \mathrm{B}$ subunit knockout mouse model and previous activin expressional studies, along with the fact that TGF- $\beta$ members are associated with normal development, differentiation, and function of the mammary gland, we hypothesize that activins, inhibins, and their related proteins are expressed in the bovine mammary gland. Therefore, we determined the expression profile of the activin-related proteins, $\beta \mathrm{A}, \beta \mathrm{B}$, and $\alpha$-inhibin subunits, and follistatin and ActRIB and ActRIIA receptors in the developing mammary gland during different stages of pregnancy that are characterized by important morphophysiological changes that will determine milk production.

\section{MATERIALS AND METHODS}

\section{Animals and Sample Collection}

All tissue samples used in the present study were collected from healthy animals that were killed routinely in the local slaughterhouse (Betim, Minas Gerais, Brazil) in compliance with all the Ministry of Agriculture regulations for animal care.

Mammary tissue from beef Nelore heifers (Bos indicus; $\mathrm{n}=29$ ) was collected and subsequently processed. Tissue samples were collected from ovary-intact nonpregnant heifers that were showing signs of diestrus (age $=18-20 \mathrm{mo} ; \mathrm{n}=9$ ). The identification of the stage of the estrous cycle was based upon the appearance of the corpus luteum (color, size, and vasculature) as described previously (Ireland et al., 1979). Mammary tissue of primigravid Nelore heifers, bred to purebred sires and carrying a single fetus, was also collected in 3 different phases: early pregnancy (d 60-120 of gestation; $\mathrm{n}=9$ ), a phase during which a massive ductal branching morphogenesis occurs; mid pregnancy (d 150-210 of gestation; $\mathrm{n}=6$ ), a phase during which an increased pattern of ductal branching and alveolar proliferation is in progress (Hovey et al., 1999, 2002); and late pregnancy (d 250-260 of gestation; $\mathrm{n}=5$ ), a phase during which the developed lobular-alveolar structures differentiate from a quiescent to a secretory stage (Hovey et al., 2002; Neville et al., 2002).

With the purpose of classifying the gestational age of the pregnant heifers so their mammary tissue could be collected, the fetal crown-rump length (CRL) was calculated by measuring the length from the fetal nose tip to the base of the tail. Results were graphically correlated with gestational age (Rexroad et al., 1974). Heifers carrying fetuses that displayed CRL between 9.3 and $27 \mathrm{~cm}$ were considered to be in the early-pregnancy stage. If the measurement of fetal CRL was between 45.4 and $78.6 \mathrm{~cm}$, heifers were considered to be in the mid-pregnancy stage. To evaluate the late-pregnancy stage, mammary tissue was collected from heifers with fetuses with CRL between 104 and $117 \mathrm{~cm}$. The Brazil- 
Table 1. Summary of fetal crown-rump length and gestational age

\begin{tabular}{|c|c|c|c|c|}
\hline Fetal crown-rump length & $\begin{array}{c}\text { Mean } \\
(\mathrm{cm})\end{array}$ & SEM & $\begin{array}{c}\text { Mean } \\
\text { calculated } \\
\text { gestational } \\
\text { age }(d)\end{array}$ & $\mathrm{n}$ \\
\hline Early pregnancy $(9.3-27 \mathrm{~cm})$ & 16.96 & 1.7 & 87.8 & 9 \\
\hline Mid pregnancy $(45.4-78.6 \mathrm{~cm})$ & 51.10 & 1.3 & 184.3 & 6 \\
\hline Late pregnancy $(104-117 \mathrm{~cm})$ & 107.84 & 1.3 & 282.8 & 5 \\
\hline
\end{tabular}

ian Association of Zebu Breeds (ABCZ, Uberaba, Minas Gerais, Brazil) accepts a gestation length of 275 to 310 d for Zebu cattle breeds (Nasser et al., 2008), whereas the estimated gestational average for the Nelore breed has been described as $284.73 \pm 3.65 \mathrm{~d}$ (Cavalcante et al., 2001). Summary of the fetal CRL and gestational age is listed in Table 1.

At slaughter, the mammary gland was immediately removed and dissected so 2 parenchymal samples from each animal could be collected from the right rear quarter. Subsequently, approximately $1 \mathrm{~cm}^{3}$ of parenchymal tissue was frozen in liquid nitrogen and stored at $-80^{\circ} \mathrm{C}$ for real-time PCR analysis. Samples for immunostaining were fixed overnight in 10\% phosphate buffered formalin, dehydrated, and embedded in paraffin.

\section{Real-Time PCR}

Total RNA was extracted from mammary tissue by the acid guanidinium thiocyanatephenol-chloroform method (Trizol Reagent, Invitrogen, Carlsbad, CA) in a proportion of $1 \mathrm{~mL} / 100 \mathrm{mg}$ of tissue. Concentration of RNA was determined by measuring absorbance at 260 $\mathrm{nm}$. The DNA contamination was removed by the use of DNase I, amplification grade (Invitrogen), and the SuperScriptTM III First-Strand Synthesis Super Mix Kit (Invitrogen) was used according to manufacturer's instructions to reverse transcribe $3 \mu \mathrm{g}$ of total RNA.
Integrity of RNA was evaluated by gel electrophoresis under denaturing conditions; intact bands were visualized by ethidium bromide staining. All PCR primers were designed with the Real Time PCR Primer Design program (Genscript Corp., Piscataway, NJ) based on sequences obtained from the National Center for Biotechnology Information database (http://www.ncbi. nlm.nih.gov/Database/index.html; Table 2). Primers were designed to span intron-exon borders whenever possible in order to avoid any accidental amplification of genomic DNA.

Real-time PCR was performed using ABI Prism 7000 SDS (Applied Biosystems, Carlsbad, CA) in a final volume of $25 \mu \mathrm{L}$ and all samples were run in duplicate. Also, $1.7 \mu \mathrm{L}$ of cDNA was added to $2 \mu \mathrm{L}$ of each primer plus $17 \mu \mathrm{L}$ of SYBR Green Master Mix (Applied Biosystems) and completed with $4.3 \mu \mathrm{L}$ of RNase-free water. Control reactions were performed omitting either the reverse transcriptase enzyme or template RNA to test for contamination with genomic DNA or nonspecific amplification. The PCR runs were programmed as follows: stage 1,1 cycle of $52^{\circ} \mathrm{C}$ for 2 min; stage 2,1 cycle of $95^{\circ} \mathrm{C}$ for $10 \mathrm{~min}$; stage 3,40 cycles of $95^{\circ} \mathrm{C}$ for $15 \mathrm{~s}$ and $50^{\circ} \mathrm{C}$ for $1 \mathrm{~min}$. Expression levels of $\beta$-actin were used as endogenous controls within each sample (Suchyta et al., 2003; Li et al., 2006) given that target and housekeeping genes had similar slopes. Positive controls consisted of cDNA from bovine ovary that is known to express activin-related proteins (Izadyar et al., 1998). Relative gene expression was calculated by the $2^{-\Delta \Delta \mathrm{CT}}$ method, where CT is cycle threshold (Livak and Schmittgen, 2001).

\section{Statistical Analysis}

For real-time PCR analysis, the $\Delta \mathrm{CT}$ values obtained for different stages of mammary gland development

Table 2. Oligonucleotide sequences used for real time PCR amplification

\begin{tabular}{|c|c|c|c|c|}
\hline Gene & Oligonucleotide & Sequence $5^{\prime} \rightarrow 3^{\prime}$ & bp & GenBank no. ${ }^{1}$ \\
\hline$\beta \mathrm{A}$ subunit $^{2}$ & $\begin{array}{l}\text { Sense } \\
\text { Antisense }\end{array}$ & $\begin{array}{l}\text { ggaatcagcacagccaggaa } \\
\text { tcctgttggccttgggaact }\end{array}$ & 117 & NM_174363 \\
\hline$\beta B$ subunit $^{2}$ & $\begin{array}{l}\text { Sense } \\
\text { Antisense }\end{array}$ & $\begin{array}{l}\text { cagcttcgccgagacagatg } \\
\text { ctggcctgcaccacaaacag }\end{array}$ & 98 & NM_176852 \\
\hline$\alpha$-Inhibin subunit & $\begin{array}{l}\text { Sense } \\
\text { Antisense }\end{array}$ & $\begin{array}{l}\text { cacgtatgtgttccagccat } \\
\text { gtctgtccagtcctgtgtgg }\end{array}$ & 86 & NM_174094 \\
\hline Follistatin & $\begin{array}{l}\text { Sense } \\
\text { Antisense }\end{array}$ & $\begin{array}{l}\text { ttctgtccaggcagctcta } \\
\text { gtcactccatcattcccaca }\end{array}$ & 126 & L21716 \\
\hline ActRIB & $\begin{array}{l}\text { Sense } \\
\text { Antisense }\end{array}$ & $\begin{array}{l}\text { gcatcaagaagaccctctcc } \\
\text { agaggtaggcctccatcgta }\end{array}$ & 137 & AY185302 \\
\hline ActRIIA & $\begin{array}{l}\text { Sense } \\
\text { Antisense }\end{array}$ & $\begin{array}{l}\text { aaagtttgaggctggcaagt } \\
\text { gcatccctttggaagttgat }\end{array}$ & 108 & U43208 \\
\hline$\beta$-Actin & $\begin{array}{l}\text { Sense } \\
\text { Antisense }\end{array}$ & $\begin{array}{l}\text { agcagatgtggatcagcaag } \\
\text { taacagtccgcttagaagca }\end{array}$ & 82 & AY141970 \\
\hline
\end{tabular}

${ }^{1}$ Source: http://www.ncbi.nlm.nih.gov/Database/index.html

${ }^{2}$ Primers spanning intron-exon borders. 
were normally distributed and therefore expressed as means \pm standard deviation and compared using 1-way ANOVA followed by Student-Newman-Keuls post hoc test for multiple comparisons. The relative mRNA concentrations are summarized as fold increase over the nonpregnant group $\left(2^{-\Delta \Delta \mathrm{CT}}\right.$; Yuan et al., 2006).

\section{Immunohistochemistry}

Paraffin-embedded bovine mammary tissue samples were sliced into $6-\mu \mathrm{m}$ serial sections and mounted on gelatinized slides. The sections from all animals were run at the same time for each antibody. After deparaffinization and rehydration through graded series of ethanol, endogenous peroxidases were then quenched with $3 \%$ (vol/vol) hydrogen peroxide solution in absolute methanol (Sigma-Aldrich, St. Louis, MO) for 10 min at room temperature. After being washed in PBS (Sigma-Aldrich), slices were incubated with normal rabbit or normal horse serum (Vector Laboratories Inc., Burlingame, CA) for $1 \mathrm{~h}$ to block nonspecific binding sites. Slides were then incubated with the primary antibodies in $0.1 \%$ BSA/PBS (Sigma-Aldrich) at $4^{\circ} \mathrm{C}$ overnight.

The primary antibodies for $\beta \mathrm{A}$ subunit, follistatin, ActRIB, and ActRIIA were kindly donated by Wylie Vale (Salk Institute, La Jolla, CA) and were used as described previously (Ciarmela et al., 2004; Florio et al., 2005; Torres et al., 2007; Ferreira et al., 2008). They were all rabbit polyclonal antisera raised against human antigens; however, activin-related proteins display $97 \%$ of homology between human and large domestic species (bovine included), which allowed us to use them in this study (Phillips, 2005). Aliquots of lyophilized whole serum were reconstituted to the original volume with distilled water and used at a final dilution 1:200 or 1:400 (for anti- $\beta$ A subunit) in PBS. The primary antibodies for $\beta B$ and $\alpha$-inhibin subunits were affinity purified goat IgG (Santa Cruz Biotechnology Inc., Santa Cruz, CA) used at final dilution 1:200 and final concentration $1 \mu \mathrm{g} / \mathrm{mL}$.

Between each step, sections were washed in PBS for 10 min. All incubations were carried out in humidified chambers to prevent evaporation. Subsequently, biotinylated secondary antibodies were added to the slices and incubated for 30 min followed by peroxidasestreptavidin incubation in $\mathrm{ABC}$ reagent (Vector Laboratories Inc.). The immunolocalization of the primary antibodies was determined with the addition of diaminobenzidine (Sigma-Aldrich) that stained the reacting sites in a brownish color. Tissue slices were counterstained with hematoxylin (Sigma-Aldrich). Negative control slices were incubated with normal serum instead of primary antibodies (for each specific antibody) and human mammary tissue was used as positive control (Reis et al., 2002; Burdette et al., 2005; Bloise et al., 2009).

\section{Assessment of Staining}

Images were acquired and analyzed on an Olympus BX-40 imaging microscope (Olympus, Center Valley, PA) and captured by a Spot camera (version 3.4.5; Sterling Heights, MI) and Corel Draw software (version 7.468; Corel Inc., Mountain View, CA). Sections were examined at $400 \times$ magnification by 3 different researchers who were blinded to groups. The percentage of epithelial and stromal cells with positive staining was graded semiquantitatively as described previously (Bloise et al., 2009; Lavalle et al., 2009) on a scale of 0 to 3 arbitrary units as follows: $0=$ less than $5 \%$ staining; $1=5$ to $10 \%$ staining; $2=10$ to $50 \%$ staining; and $3=$ more than $50 \%$ of the cells stained positively. The possible association between staining scores and gestational age (surrogated by CRL) was assessed by nonlinear regression analysis (Prism 4.0, GraphPad, La Jolla, CA).

\section{RESULTS}

To address the question of whether activin-related proteins are expressed in the bovine mammary tissue at multiple phases of gestational mammary development and differentiation, we examined $\beta \mathrm{A}, \beta \mathrm{B}$, and $\alpha$-inhibin subunits, follistatin, and ActRIB and ActRIIA receptors mRNA and protein expression using real-time PCR and immunohistochemistry. Their transcripts profiles are shown in Figure 1 and their tissue localization is shown in the Figure 2. Real-time PCR control reactions were negative, ruling out genomic DNA contamination. The mammary tissue of nonpregnant heifers displayed profuse adipose tissue with small rudimentary branched structures, as expected, whereas the mammary parenchyma in primigravid heifers progressed from organized undifferentiated ductal units to enlarged lobuloalveolar glands. Positive control slices showed the expected staining, whereas the negative control tissue sections showed no detectable staining (data not shown).

\section{Activin and Inhibin Subunit mRNA and Protein Expression}

The mRNA expression of $\beta \mathrm{A}$ and $\alpha$-inhibin subunits was significantly higher during early pregnancy (3.6and 2.9-fold increase over nonpregnant group for $\beta \mathrm{A}$ and $\alpha$-inhibin subunits, respectively; $P<0.05)$ and mid pregnancy (4.3- and 3.0-fold increase; $P<0.05$ ). Conversely, $\beta \mathrm{B}$ subunit transcripts were higher only in 
the mid-pregnancy group $(2.3$-fold increase; $P<0.05$; Figure 1).

Activin and inhibin subunits immunostaining was cytoplasmic and nuclear. Signals of $\beta$ A subunit staining were present mainly in luminal epithelial cells in nonpregnant heifers (Figure 2A), and the area of $\beta \mathrm{A}$ subunit immunostaining increased across gestation (Table 3).

On the other hand, $\beta \mathrm{B}$ and $\alpha$-inhibin subunit signals were present in cells surrounding luminal epitheliums in nonpregnant heifers (Figures $2 \mathrm{E}$ and I). In mam- mary glands from pregnant heifers, however, staining signals were found mainly in luminal epithelial cells and stromal region but not in cells surrounding luminal epithelial cells (Figure $2 \mathrm{~F}-\mathrm{H}$ and $\mathrm{J}-\mathrm{L}$ ). Similar to $\beta \mathrm{A}$ subunit, the area of immunostaining for the subunits $\beta \mathrm{B}$ and $\alpha$-inhibin increased across gestation (Table 3 ). The increase of all activin and inhibin subunits across gestation was confirmed by nonlinear regression analysis, showing a positive association between the stained area for $\beta \mathrm{A}, \beta \mathrm{B}$, and $\alpha$-inhibin subunits and the $\mathrm{CRL}$ $\left(\mathrm{R}^{2} \approx 0.70\right.$ for each of the 3 subunits vs. CRL).
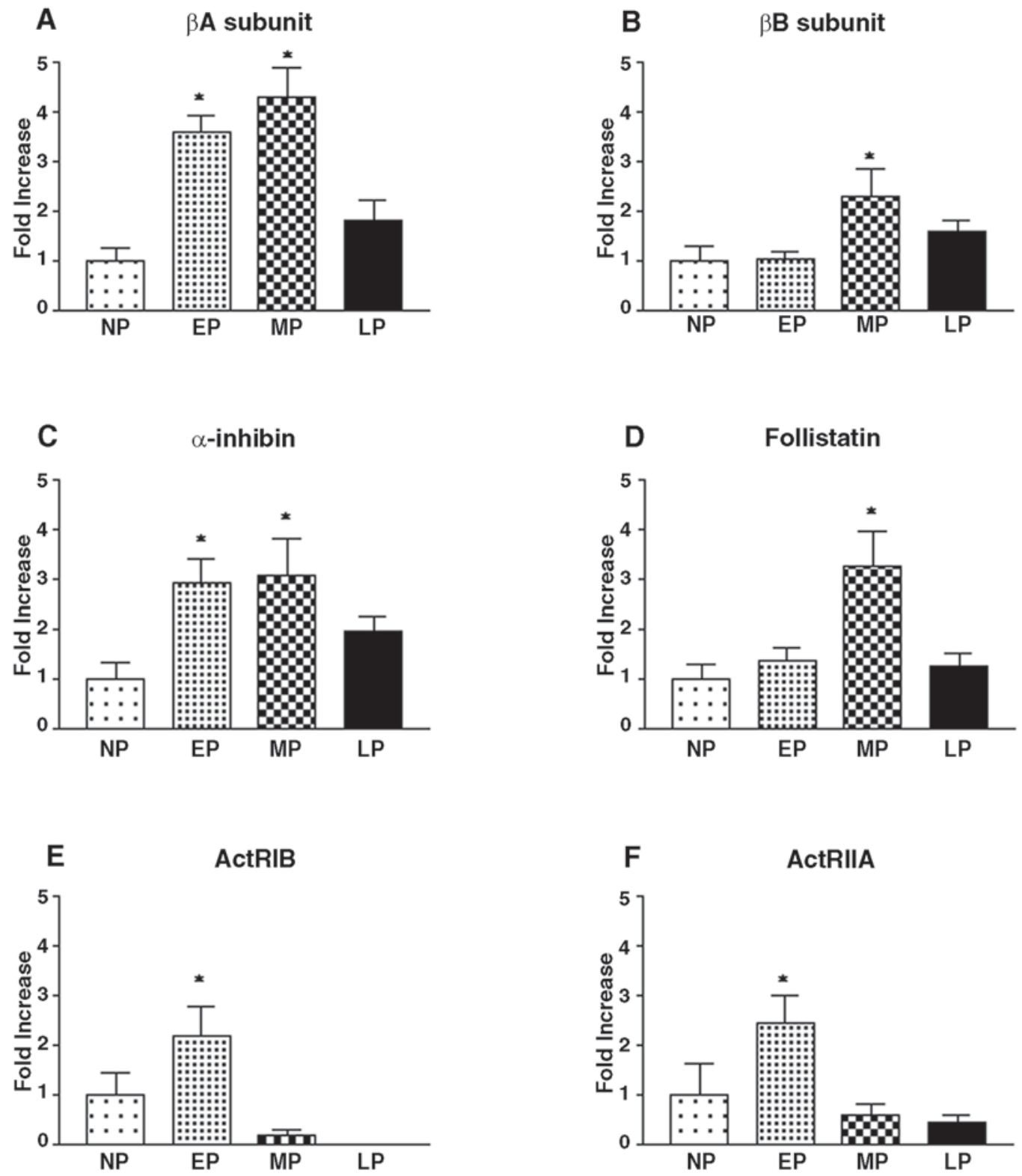

Figure 1. Messenger RNA expression of $\beta$ A (A) and $\beta B$ subunits (B), $\alpha$-inhibin subunit (C), follistatin (D), and activin receptors ActRIB (E) and ActRIIA (F) in the bovine mammary gland in nonpregnant (NP) heifers and primigravid heifers during early pregnancy (EP), mid pregnancy (MP), and late pregnancy (LP). ${ }^{*} P<0.05$ compared with NP stage (1-way ANOVA and Student-Newman-Keuls test). 


\section{Follistatin mRNA and Protein Expression}

Follistatin mRNA expression showed a significant increase during mid pregnancy (3.7-fold increase; $P<$ 0.05 ; Figure 1D). Immunostaining for follistatin was present both in the cytoplasm and nucleus at all stages investigated and staining signals were present mainly in luminal epithelial cells in nonpregnant heifers (Figure $2 \mathrm{M}$ ) and during all gestational phases analyzed (Figures $2 \mathrm{~N}-\mathrm{P})$. Follistatin area of immunostaining to the same

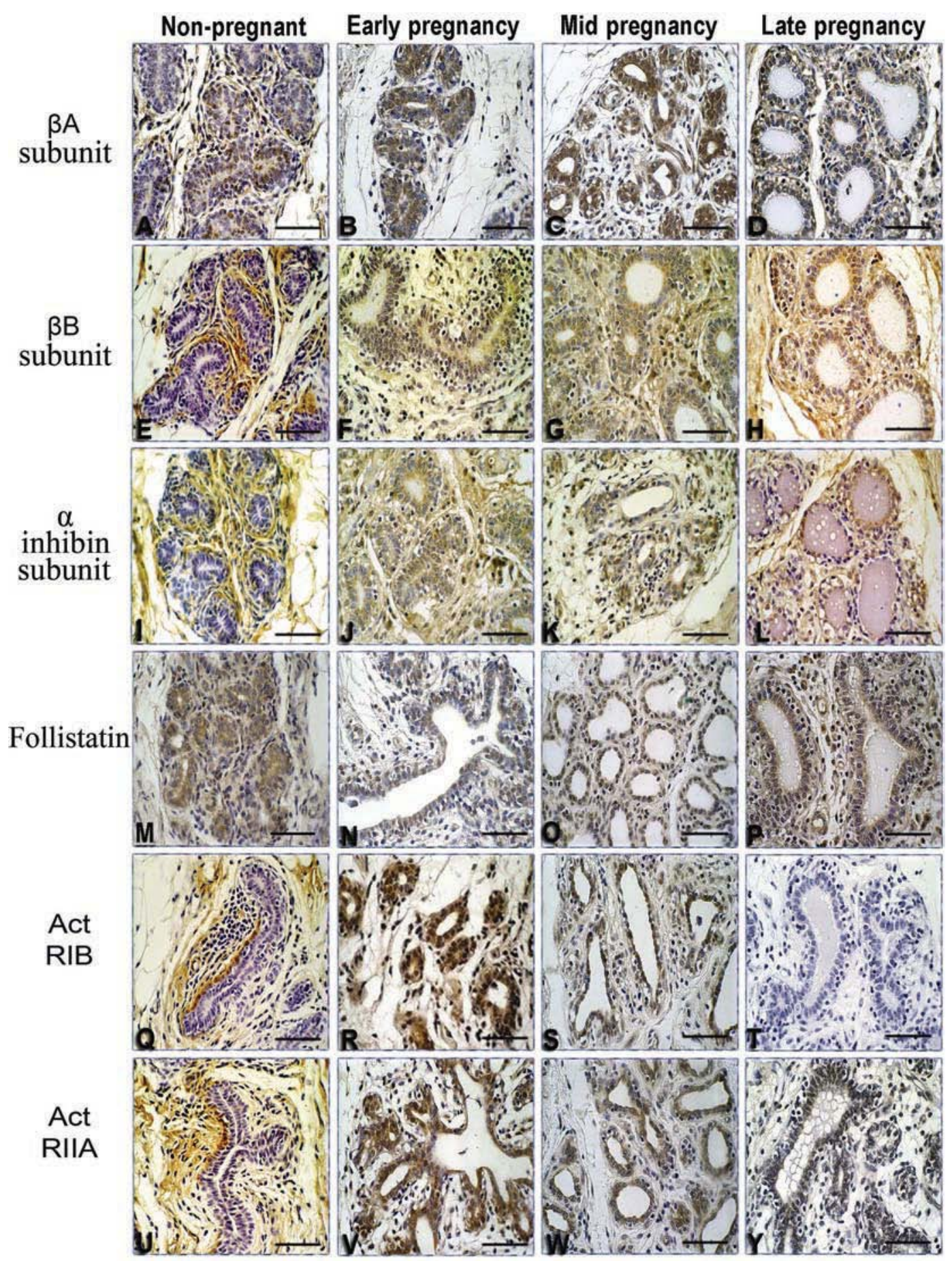

Figure 2. Immunohistochemistry for $\beta \mathrm{A}(\mathrm{A}-\mathrm{D}), \beta \mathrm{B}(\mathrm{E}-\mathrm{H})$, and $\alpha$-inhibin (I-L) subunits, follistatin $(\mathrm{M}-\mathrm{P})$, ActRIB (Q-T), and ActRIIA $(\mathrm{U}-\mathrm{Z})$ in the bovine mammary gland in nonpregnant heifers and in primigravid heifers during early, mid, and late pregnancy. Bar $=50 \mu \mathrm{m}$. Color version available in the online PDF. 
Table 3. Summary of activin-related protein area of immunostaining for the mammary gland of nonpregnant (NP) heifers and primigravid heifers during early pregnancy (EP), mid pregnancy (MP), and late pregnancy $(\mathrm{LP})^{1}$

\begin{tabular}{|c|c|c|c|c|c|c|c|c|}
\hline \multirow[b]{2}{*}{ Antibody } & \multicolumn{4}{|c|}{ Epithelial cells } & \multicolumn{4}{|c|}{ Stromal cells } \\
\hline & NP & $\mathrm{EP}$ & MP & LP & NP & $\mathrm{EB}$ & $\mathrm{MP}$ & LP \\
\hline$\beta$ A subunit & + & ++ & +++ & +++ & + & ++ & ++ & ++ \\
\hline$\beta B$ subunit & + & ++ & +++ & +++ & + & ++ & ++ & ++ \\
\hline$\alpha$-Inhibin subunit & + & ++ & +++ & +++ & + & ++ & ++ & ++ \\
\hline Follistatin & + & ++ & ++ & +++ & + & ++ & ++ & ++ \\
\hline ActRIB & + & ++ & ++ & - & + & ++ & ++ & - \\
\hline ActRIIA & + & ++ & ++ & + & + & ++ & ++ & + \\
\hline
\end{tabular}

${ }^{1}$ Area of immunostaining was graded as follows: less than $5 \%$ staining $(-$, score 0$)$; up to $10 \%(+$, score 1$)$; $10-50 \%(++$, score 2$)$; or more than $50 \%(+++$, score 3$)$. The table shows the median values for each protein evaluated.

extent as for activin and inhibin subunits increased across the gestational progression (Table 3).

\section{Activin Receptor mRNA and Protein Expression}

Transcripts of ActRIB and ActRIIA were both significantly higher in the early-pregnancy group (2.2- and 2.6 -fold increase, respectively; $P<0.05$; Figures $1 \mathrm{E}$ and F); ActRIB mRNA was not detected in the latepregnancy group (Figure 1E). In the mammary tissue of nonpregnant heifers, activin receptors were localized mostly in the cytoplasm of the luminal epithelial cells (Figures 2Q and U); during gestation, they were present in both cytoplasm and nucleus of the epithelial cells and in the cytoplasm of the stromal cells. Signals were localized mainly in the luminal cells during gestation (Figures 2R-S and $\mathrm{V}-\mathrm{W}$ ), whereas, in accordance with the transcripts analysis, no staining signal was found for the ActRIB receptor in the late-pregnancy group (Figure 2T).

The ActRIB area of immunostaining increased in early- and mid-pregnancy stages and was absent in the late-pregnancy stage (Table 2). The ActRIIA area of staining followed the same pattern as described for ActRIB but was present in less than $10 \%$ of the epithelial cells during late pregnancy (Tables 2 and 3 ).

\section{DISCUSSION}

The present study showed for the first time the expression of activin-related proteins in the mammary gland of nonpregnant and pregnant heifers during early, mid, and late pregnancy. Activin-related proteins mRNA expression was higher in the mammary tissue of early- and mid-pregnant animals, suggesting a role for activin in the establishment of the mammary treelike structure. Their staining pattern demonstrated that they are expressed mainly in luminal epithelial cells across gestation. The proportion of luminal epi- thelial cells increases during gestational processes and achieves full development during late pregnancy, which could explain, at least in part, their increased mRNA expression observed in early or mid pregnancy or both. However, activin-related proteins expression is downregulated during late pregnancy even though their area of immunostaining is present in more than $50 \%$ of the cells. These data suggest that an increased stained population of luminal epithelial cells is not responsible for an increased pattern of mRNA expression found in the early- and mid-pregnancy stages, raising the question of how those growth factors are regulated in the bovine mammary gland across gestation.

Mammary activin-related proteins expression could be influenced by hormonal changes that take place during gestation. Pregnancy steroid hormones such as estrogen and progesterone coordinate multiple stages of mammary growth, differentiation, secretory activity, and involution (Connor et al., 2007). In cattle, blood serum estrogen levels increase approximately 10-fold 1 mo before parturition, with the most dramatic increase occurring during the last $5 \mathrm{~d}$ of gestation (Barth et al., 1978). Progesterone levels, in turn, are higher throughout gestation and decline about $10 \mathrm{~d}$ before parturition (Stabenfeldt et al., 1970). Estrogen plays a role in regulating activin's downstream pathways, as shown in MCF7 breast cancer cells, where a crosstalk between estrogen and activin has been demonstrated (Burdette and Woodruff, 2007). In fact, estrogen and activin signaling cascades intersect and repress each other's transcription pathways. Additionally, estrogen is able to reduce the amount of $\beta \mathrm{B}$ subunit mRNA and protein produced by the same cells (Burdette and Woodruff, 2007). Altogether, in the bovine mammary gland, estrogen may play a role regulating $\beta \mathrm{A}$ and $\beta \mathrm{B}$ subunits expression because, during gestation, both are downregulated in stages where estrogen levels are increased the most. Progesterone in turn plays a tissue-specific role in regulating $\beta \mathrm{A}$ subunit expression. In cultured 
human endometrial stromal cells, $\beta$ A subunit mRNA expression is upregulated after progesterone exposure (Florio et al., 2007), whereas in the myometrium of ovariectomized and steroid-replaced rats, progesterone decreased $\beta \mathrm{A}$ subunit mRNA expression (Ciarmela et al., 2009). However, here we demonstrate that during gestational phases in which blood progesterone levels are present in high concentrations, $\beta \mathrm{A}$ and $\beta \mathrm{B}$ subunits are overexpressed, suggesting then a role for progesterone in regulating $\beta \mathrm{A}$ and $\beta \mathrm{B}$ subunits expression in the mammary tissue of pregnant animals. Therefore, steroid hormones might regulate expression of activinrelated proteins in the mammary gland, a hypothesis that will require further investigation.

The observation that $\beta \mathrm{B}$ subunit pattern of mRNA expression does not follow those from $\beta \mathrm{A}$ and $\alpha$-inhibin subunits (i.e., $\beta \mathrm{B}$ subunit transcript levels are higher only in mid-pregnant animals) suggests that activins and inhibins $\mathrm{A}$ and $\mathrm{B}$ may play a different regulatory role during epithelial branching and proliferation.

Regarding activins physiological antagonists, $\alpha$-inhibin subunit mRNA expression was increased in early- and mid-pregnant animals, whereas follistatin was increased only in mid-pregnant animals. The observation that $\alpha$-inhibin subunit and follistatin staining localization matched those from $\beta \mathrm{A}$ and $\beta \mathrm{B}$ subunits (i.e., the staining signals were mainly found in luminal epithelial cells during all gestational phases analyzed) suggests a potential interaction of these regulatory factors in regulating mammary growth. Furthermore, these findings suggest that both inhibins and follistatin may function as activin antagonists in different time points during mammary epithelial proliferative processes.

Recently, it has been described that follistatin is overexpressed in breast proliferative diseases such as breast fibroadenoma, demonstrating a role in regulating mammary gland proliferation (Bloise et al., 2009). Moreover, follistatin also binds and neutralizes another TGF- $\beta$ superfamily growth factor member named myostatin (Hill et al., 2002). This molecule regulates skeletal muscle mass (Lee and Mcpherron, 2001) and its expression has been characterized in different stages of porcine mammary gland development (Ji et al., 1998). In bovine adipocytes, activins and myostatin impair preadipocytes differentiation (Hirai et al., 2007), which is essential for the growth of the mammary tree-like structure (Hovey et al., 1999; Hinck and Silberstein, 2005).

\section{CONCLUSIONS}

The present study provides the first report of the activin-related proteins presence in the bovine mammary gland. Different patterns of expression during bo- vine gestational mammary gland development and differentiation were detected and their tissue and cellular localization changed depending on the protein and on the gestational phase analyzed. The modulation of the expression levels suggests a role for activins in regulating mammary branching morphogenesis and epithelial differentiation, which could be highly relevant to the molecular mechanisms leading to milk production.

\section{ACKNOWLEDGMENTS}

This research was supported by $\mathrm{CNPq}$ (Conselho Nacional de Desenvolvimento Científico e Tecnológico, Brasilia, Brazil). We thank Wylie Vale (Salk Institute, La Jolla, CA) for donating the primary antibodies used in the present study; Janine Ivo, Patricia Mitre (both of Department of Physiology and Biophysics, UFMG, Belo Horizonte, Brazil), and Maristane Freire de Paula (Department of Morphology, UFMG, Belo Horizonte, Brazil) for technical assistance; and Lydia Kostopoulos (Department of Political Sciences, University of Siena, Siena, Italy) for proofreading. Publication supported by Coordenação de Aperfeiçoamento de Pessoal de Nível Superior (CAPES, Brasilia, Brazil).

\section{REFERENCES}

Akers, R. M. 2006. Major advances associated with hormone and growth factor regulation of mammary growth and lactation in dairy cows. J. Dairy Sci. 89:1222-1234.

Barth, A. D., W. M. Adams, J. C. Manns, and N. C. Rawlings. 1978. Induction of parturition in beef cattle using estrogens in conjunction with dexamethasone. Can. Vet. J. 19:175-180.

Bierie, B., A. E. Gorska, D. G. Stover, and H. L. Moses. 2009. TGFbeta promotes cell death and suppresses lactation during the second stage of mammary involution. J. Cell. Physiol. 219:57-68.

Bilezikjian, L. M., A. L. Blount, C. J. Donaldson, and W. W. Vale. 2006. Pituitary actions of ligands of the TGF-beta family: Activins and inhibins. Reproduction 132:207-215.

Bloise, E., H. L. Couto, L. Massai, P. Ciarmela, M. Mencarelli, L. E. Borges, M. Muscettolla, G. Grasso, V. F. Amaral, G. D. Cassali, F. Petraglia, and F. M. Reis. 2009. Differential expression of follistatin and FLRG in human breast proliferative disorders. BMC Cancer 9:320

Burdette, J. E., J. S. Jeruss, S. J. Kurley, E. I. Lee, and T. K. Woodruff. 2005. Activin A mediates growth inhibition and cell cycle arrest through Smads in human breast cancer cells. Cancer Res. 65:7968-7975.

Burdette, J. E., and T. K. Woodruff. 2007. Activin and estrogen crosstalk regulates transcription in human breast cancer cells. Endocr. Relat. Cancer 14:679-689.

Bussmann, U. A., G. M. Lanuza, and L. E. Bussmann. 2004. Activin and follistatin in rat mammary gland. Mol. Cell. Endocrinol. 221:9-19.

Cavalcante, F. A., R. M. Filho, C. C. Campello, R. N. B. Lobo, and G. A. Martins. 2001. Gestation length of Nellore cattle in the Oriental Amazônia. Rev. Bras. Zootec. 30:1451-1455.

Ciarmela, P., P. Florio, M. Sigurdardottir, P. Toti, V. Maguer-Satta, R. Rimokh, A. Altomare, P. Tosi, and F. Petraglia. 2004. Follistatin-related gene expression, but not follistatin expression, is decreased in human endometrial adenocarcinoma. Eur. J. Endocrinol. 151:251-257. 
Ciarmela, P., E. Wiater, S. M. Smith, and W. Vale. 2009. Presence, actions, and regulation of myostatin in rat uterus and myometrial cells. Endocrinology 150:906-914.

Cocolakis, E., M. Dai, L. Drevet, J. Ho, E. Haines, S. Ali, and J. J. Lebrun. 2008. Smad signaling antagonizes STAT5-mediated gene transcription and mammary epithelial cell differentiation. J. Biol. Chem. 283:1293-1307.

Connor, E. E., M. J. Meyer, R. W. Li, M. E. Van Amburgh, Y. R. Boisclair, and A. V. Capuco. 2007. Regulation of gene expression in the bovine mammary gland by ovarian steroids. J. Dairy Sci. 90(Suppl. 1):E55-E65.

Daniel, C. W., S. Robinson, and G. B. Silberstein. 2001. The transforming growth factors beta in development and functional differentiation of the mouse mammary gland. Adv. Exp. Med. Biol. 501:61-70.

Feng, X. H., and R. Derynck. 2005. Specificity and versatility in TGF-beta signaling through Smads. Annu. Rev. Cell Dev. Biol. 21:659-693.

Ferreira, M. C., I. K. Cavallo, P. Florio, F. Petraglia, and F. M. Reis. 2008. Activin betaA subunit, follistatin and follistatin-like 3 are expressed in the endometrium of ovariectomized rats and regulated by estrogen replacement. J. Mol. Histol. 39:535-541.

Florio, P., P. Ciarmela, F. M. Reis, P. Toti, L. Galleri, R. Santopietro, E. Tiso, P. Tosi, and F. Petraglia. 2005. Inhibin alpha-subunit and the inhibin coreceptor betaglycan are downregulated in endometrial carcinoma. Eur. J. Endocrinol. 152:277-284

Florio, P., M. Rossi, P. Viganò, S. Luisi, M. Torricelli, P. B. Torres, A. M. Di Blasio, and F. Petraglia. 2007. Interleukin 1beta and progesterone stimulate activin A expression and secretion from cultured human endometrial stromal cells. Reprod. Sci. 14:29-36.

Harrison, C. A., P. C. Gray, W. W. Vale, and M. D. Robertson. 2005. Antagonists of activin signaling: Mechanisms and potential biological applications. Trends Endocrinol. Metab. 16:73-78.

Hill, J. J., M. V. Davies, A. A. Pearson, J. H. Wang, R. M. Hewick, N. M. Wolfman, and Y. Qiu. 2002. The myostatin propeptide and the follistatin-related gene are inhibitory binding proteins of myostatin in normal serum. J. Biol. Chem. 277:40735-40741.

Hinck, L., and G. B. Silberstein. 2005. Key stages in mammary gland development: The mammary end bud as a motile organ. Breast Cancer Res. 7:245-251.

Hirai, S., H. Matsumoto, N. Hino, H. Kawachi, T. Matsui, and H. Yano. 2007. Myostatin inhibits differentiation of bovine preadipocyte. Domest. Anim. Endocrinol. 32:1-14.

Hovey, R. C., T. B. Mcfadden, and R. M. Akers. 1999. Regulation of mammary gland growth and morphogenesis by the mammary fat pad: A species comparison. J. Mammary Gland Biol. Neoplasia 4:53-68.

Hovey, R. C., J. F. Trott, and B. K. Vonderhaar. 2002. Establishing a framework for the functional mammary gland: From endocrinology to morphology. J. Mammary Gland Biol. Neoplasia 7:17-38.

Ireland, J. J., P. B. Coulson, and R. L. Murpher. 1979. Follicular development during four stages of the estrous cycle of beef cattle. J. Anim. Sci. 49:1261-1269.

Izadyar, F., G. Dijkstra, H. T. Van Tol, A. J. Van den Eijnden-van Raaij, R. Van den Hurk, B. Colenbrander, and M. M. Bevers. 1998. Immunohistochemical localization and mRNA expression of activin, inhibin, follistatin, and activin receptor in bovine cumulus-oocyte complexes during in vitro maturation. Mol. Reprod. Dev. 49:186-195.

Jeruss, J. S., J. Y. Santiago, and T. K. Woodruff. 2003. Localization of activin and inhibin subunits, receptors and SMADs in the mouse mammary gland. Mol. Cell. Endocrinol. 203:185-196.

Ji, S., R. L. Losinski, S. G. Cornelius, G. R. Frank, G. M. Willis, D. E. Gerrard, F. F. Depreux, and M. E. Spurlock. 1998. Myostatin expression in porcine tissues: Tissue specificity and developmental and postnatal regulation. Am. J. Physiol. 275:R1265-R1273.

Komatsu, Y., G. Scott, A. Nagy, V. Kaartinen, and Y. Mishina 2007. BMP type I receptor ALK2 is essential for proper patterning at late gastrulation during mouse embryogenesis. Dev. Dyn. $236: 512-517$
Lavalle, G. E., A. C. Bertagnolli, W. L. Tavares, and G. D. Cassali. 2009. Cox-2 expression in canine mammary carcinomas: Correlation with angiogenesis and overall survival. Vet. Pathol. 46:12751280.

Lee, S. J., and A. C. Mcpherron. 2001. Regulation of myostatin activity and muscle growth. Proc. Natl. Acad. Sci. USA 98:9306-9311.

Li, R. W., M. J. Meyer, C. P. Van Tassell, T. S. Sonstegard, E. E. Connor, M. E. Van Amburgh, Y. R. Boisclair, and A. V. Capuco. 2006 Identification of estrogen-responsive genes in the parenchyma and fat. Physiol. Genomics 27:42-53.

Lin, S. J., T. F. Lerch, R. W. Cook, T. S. Jardetzky, and T. K. Woodruff. 2006. The structural basis of TGF-beta, bone morphogenetic protein, and activin ligand binding. Reproduction 132:179-190.

Liu, Q. Y., B. Niranjan, P. Gomes, J. J. Gomm, D. Davies, R. C. Coombes, and L. Buluwela. 1996. Inhibitory effects of activin on the growth and morphogenesis of primary and transformed mammary epithelial cells. Cancer Res. 56:1155-1163.

Livak, K. J., and T. D. Schmittgen. 2001. Analysis of relative gene expression data using real-time quantitative PCR and the 2(-delta delta $\mathrm{C}(\mathrm{T})$ ) method. Methods 25:402-408.

Manickam, R., R. N. Pena, and C. B. Whitelaw. 2008. Mammary gland differentiation inversely correlates with GDF-8 expression. Mol. Reprod. Dev. 75:1783-1788.

Montesano, R., F. Carrozzino, and P. Soulié. 2007. Low concentrations of transforming growth factor-beta-1 induce tubulogenesis in cultured mammary epithelial cells. BMC Dev. Biol. 7:7.

Montesano, R., R. Sarközi, and H. Schramek. 2008. Bone morphogenetic protein-4 strongly potentiates growth factor-induced proliferation of mammary epithelial cells. Biochem. Biophys. Res. Commun. 374:164-168.

Muttukrishna, S., D. Tannetta, N. Groome, and I. Sargent. 2004. Activin and follistatin in female reproduction. Mol. Cell. Endocrinol. 225:45-56.

Nasser, L. F., L. F. Rezende, G. A. Bó, and A. Barth. 2008. Induction of parturition in Zebu-cross recipients carrying in vitro-produced Bos indicus embryos. Theriogenology 69:116-123.

Nelson, C. M., M. M. Vanduijn, J. L. Inman, D. A. Fletcher, and M. J. Bissell. 2006. Tissue geometry determines sites of mammary branching morphogenesis in organotypic cultures. Science 314:298-300.

Neville, M. C., T. B. McFadden, and I. Forsyth. 2002. Hormonal regulation of mammary differentiation and milk secretion. J. Mammary Gland Biol. Neoplasia 7:49-66.

Phillips, D. J. 2005. Activins, inhibins and follistatins in the large domestic species. Domest. Anim. Endocrinol. 28:1-16.

Plath, A., R. Einspanier, F. Peters, F. Sinowatz, and D. Schams. 1997 Expression of transforming growth factors alpha and beta-1 messenger RNA in the bovine mammary gland during different stages of development and lactation. J. Endocrinol. 155:501-511.

Reis, F. M., L. Cobellis, L. C. Tameirao, G. Anania, S. Luisi, I. S. Silva, W. Gioffre, A. M. Di Blasio, and F. Petraglia. 2002. Serum and tissue expression of activin A in postmenopausal women with breast cancer. J. Clin. Endocrinol. Metab. 87:2277-2282.

Rexroad, J., L. E. Casida, and E. J. Tyler. 1974. Crown-rump length of fetuses in purebred Holstein-Friesian cows. J. Dairy Sci. $57: 346-347$

Robinson, G. W., and L. Hennighausen. 1997. Inhibins and activins regulate mammary epithelial cell differentiation through mesenchymal epithelial interactions. Development 124:2701-2708.

Saito, S., Y. Sidis, A. Mukherjee, Y. Xia, and A. Schneyer. 2005. Differential biosynthesis and intracellular transport of follistatin isoforms and follistatin-like-3. Endocrinology 146:5052-5062.

Schmierer, B., and C. S. Hill. 2007. TGFbeta-SMAD signal transduction: Molecular specificity and functional flexibility. Nat. Rev. Mol. Cell Biol. 8:970-982.

Schneyer, A. L., Q. Wang, Y. Sidis, and P. M. Sluss. 2004. Differential distribution of follistatin isoforms: Application of a new FS315-specific immunoassay. J. Clin. Endocrinol. Metab. 89:5067-5075.

Sidis, Y., D. V. Tortoriello, W. E. Holmes, Y. Pan, H. T. Keutmann, and A. L. Schneyer. 2002. Follistatin-related protein and follistatin 
differentially neutralize endogenous vs. exogenous activin. Endocrinology 143:1613-1624.

Stabenfeldt, G. H., B. I. Osburn, and L. L. Ewing. 1970. Peripheral plasma progesterone levels in the cow during pregnancy and parturition. Am. J. Physiol. 218:571-575.

Suchyta, S. P., S. Sipkovsky, R. G. Halgren, R. Kruska, M. Elftman, M. Weber-Nielsen, M. J. Vandehaar, L. Xiao, R. J. Tempelman, and P. M. Coussens. 2003. Bovine mammary gene expression pro- filing using a cDNA microarray enhanced for mammary-specific transcripts. Physiol. Genomics 16:8-18.

Torres, P. B., P. Florio, M. C. Ferreira, M. Torricelli, F. M. Reis, and F. Petraglia. 2007. Deranged expression of follistatin and follistatin-like protein in women with ovarian endometriosis. Fertil. Steril. 88:200-205.

Yuan, J. S., A. Reed, F. Chen, and C. N. Stewart Jr.. 2006. Statistical analysis of real-time PCR data. BMC Bioinformatics 7:85. 